UDC $613,614,616.9$

DOI: $10.21668 /$ health.risk/2019.2.02.eng

\title{
SCIENTIFIC AND METHODOLOGICAL ASPECTS OF LABPRATORY SUPPORT AIMED AT PROVIDING CHEMICAL SAFETY DURING INTERNAITONAL MASS EVENTS
}

\author{
A.Yu. Popova ${ }^{1}$, N.V. Zaitseva ${ }^{2}$, G.V. Karpushchenko ${ }^{3}$ \\ ${ }^{1}$ Russian Medical Academy of Postgraduate Education, 2/1 Barrikadnaya Str., Moscow, 123995, Russian Federation \\ ${ }^{2}$ Federal Scientific Center for Medical and Preventive Health Risk Management Technologies, 82 Monastyrskaya Str., \\ Perm, 614045, Russian Federation \\ ${ }^{3}$ Hygiene and Epidemiology Center in Rostov region, 67 7th line Str., Rostov-on-Don, 344019, Russian Federation
}

International legal acts that regulate organizing and carrying out various mass events in our country impose an obligation on the RF to provide safety, including sanitary-epidemiologic ones, for their guests and participants. Tight schedules and short time span are peculiarities related to such events and, when it comes to hygienic aspects, it determines short-term exposure of guests and participants to environmental factors. Nowadays in Russia substantial experience has been accumulated in providing hygienic safety for population during international mass events.

Our research goal was to determine priority tasks in laboratory and information-analytical support for Rospotrebnadzor activities aimed at solving issues related hygienic safety of international mass events at various stages in preparation to them and during them depending on their scale and social significance.

This paper focuses on determining a necessity to work out a model for laboratory support aimed at providing chemical safety during international mass events as regards assessing health risks for participants and guests attending such events; the model is to involve implementing laboratory control over biological markers. The authors determine basic principles of the state policy in the sphere of providing hygienic safety, reasons for threats and health risks occurrence during international mass events. The present research allowed to reveal it was advisory to implement a system for biological control over markers related to impacts exerted by various chemicals on personnel involved into preparation and organization of international mass events.

Key words: international event, mass event, hygienic safety, laboratory support, information and analytical support, sanitary-epidemiologic welfare, state regulation, safe environment.

According to Clause 15, Part 4, of the RF Constitution, generally accepted principles and norms of the international law as well as international treaties signed by the RF are an integral part of the legal system in the country. If an international treaty signed by the RF fixes rules that are different from those fixed in the national legislation, than it is these rules that are to be applied.
International legal acts that determine organization of various global mass events on the RF territory commit The Russian Federation to provide their safety, including sanitary-epidemiologic welfare of their guests and participants [1].

World practice in organizing and holding global mass events ${ }^{1}$ proves that greater attention is being paid now to issues related to hygienic safety provision [1-5].

(C) Popova A.Yu., Zaitseva N.V., Karpushchenko G.V., 2019

Anna Yu. Popova - Doctor of Medicine, Professor, Head of Department of organization of sanitary and epidemiological service (e-mail: rmapo@rmapo.ru, tel.: 8 (499) 458-95-63; ORCID: https://orcid.org/0000-0002-4315-5307).

Nina V. Zaitseva - Academician of the Russian Academy of Sciences, Doctor of Medical Sciences, Professor, Scientific Director (e-mail: znv@fcrisk.ru; tel.: +7 (342) 237-25-34; ORCID: https://orcid.org/0000-0003-2356-1145).

Garri V. Karpushchenko - Candidate of Medical Sciences, Chief Physician (e-mail: master@donses.ru; tel.: +7 (863) 251-04-92); https://orcid.org/0000-0003-4672-8753).

${ }^{1}$ WHO Report. Global mass events: their significance and possibilities for providing health safety in the world [Websource]. - 2011. - URL: http://apps.who.int/iris/bitstrem/10665/25910/1/B130-17-ru.pdf (date of visit March 12, 2019). 
At present there is an integrated system that has been created in the RF and significant experience has been accumulated in the sphere of providing hygienic safety of the population, including global mass events $[3-5,7,9]$. Hygienic safety is determined by state authorities being well-prepared to prevent threats and risks caused by chemical or physical impacts and related to a global mass event ${ }^{1}[10]$.

There are some basic principles of the state policy aimed at providing hygienic safety of the population. They are:

- a person's right to live in a safe environment;

- absence of unacceptable health risks related to conditions and factors of a global mass event;

- adherence to generally accepted international legal norms in the sphere of providing hygienic safety;

- coordinated interaction and mutual responsibility borne by all the structures that are to provide hygienic safety of a global mass event being held;

- providing information about risks to executive authorities and officials who are responsible for making managerial decisions;

- relevant state regulation of threats and risks for hygienic safety ;

- setting tasks solution to which will enable determining conceptual and methodical grounds for laboratory and informationalanalytical support necessary to provide hygienic safety during glopal mass events [1].

Our research goal was to determine priority tasks which were to be solved to provide necessary laboratory and informationanalytical support for Rospotrebnadzor's bodies and their activities aimed at securing hygienic safety of global mass events at different stages including preparation to them depending on their scale and social significance.

Hygienic safety includes a chemical and a physical aspect and their combination is an integral system but it is scientifically reasonable to explore them separately.

According to the RF President Order No. 202 dated May 09, 2017 all the enterprises that were located on territories where FIFA 2018 World Cup events were taking place and that dealt with hazardous productions or applied chemical substances or toxicants had to suspend their activities until these event were over ${ }^{2}$.

Experience accumulated in the sphere of providing chemical safety of the population, including global mass events, allowed adjusting "The Basics of the state policy in chemical safety sphere approved by the RF President on November 1, 2013». The RF President Order No. 97 dated March 11, 2019, approved «The Basics of the RF state policy in the sphere of providing chemical and biological safety up to 2025 and beyond» ${ }^{3}$.

The above-mentioned legal act fixes the following primary threats:

- spread and (or) application of chemical weapons, terrorists attacks that involve use of potentially hazardous chemicals;

- growing globalization of the world trade and persisting probability that potentially hazardous chemicals or products made out of them can be imported onto the RF territory;

- use of technologies that can't provide proper chemical safety;

\footnotetext{
${ }^{2}$ The RF President Order No. 202 dated May 09, 2017. On peculiarities related to implementing reinforced security measures for a period during which FIFA 2018 World Cup and FIFA 2017 Confederation Cup events are to take place in the RF [Web-source] // KonsultantPlus. - URL: http:www.consultant.ru/cons_doc (date of visit May 20, 2019).

${ }^{3}$ The RF President Order No. 97 dated March 11, 2019 [Web-source] // KonsultantPlus. - URL: http:www. consultant.ru/cons_doc (date of visit April 18, 2019).
} 
- growing number of organizations that manufacture chemical products, substantial growth in volumes of chemical wastes, absence of efficient technologies regarding chemically dangerous wastes processing and reclamation of contaminated territories;

- accidents at chemical objects caused by critical wear and tear of equipment, technological processes becoming more complicated, and production personnel not being sufficiently qualified;

- a great number of potentially hazardous chemical objects that are either no longer exploited or their technical and technological resources are close to their limits or completely exhausted as well as territories that have been contaminated due to economic activities;

- development and manufacture of completely new chemicals that produce their effects on people and the environment but these effects haven't been studied in depth;

- wide use of highly toxic chemicals and accumulation of hazardous chemically stable compounds in the environment.

To eliminate or minimize all the abovementioned threats as much as it was only possible was one of the basic tasks during global mass events that were held in the RF; to solve it, it was necessary to determine primary causes of threats and health risks for those who visited a global mass event or participated in it [9].

We highlighted the following primary causes for threats and health risks among the overall pool:

- activities performed by economic entities that belonged to 1-4 hazard category as per possible damage to health in case obligatory requirements fixed in the sanitary legislation were violated;

- terroristic threats;

- high population density within a limited space;
- high probability of vast crowds and them coming out of control in case a chemical agent occurs;

- limited possibility to provide control due to participants of an event being diverse;

- limited number of points where access to vital resources could be provided;

- logistics and transportation schemes failure;

- ecologically unstable technogenic objects and hazardous environmental objects that are located in the close proximity to a place where a global mass event is held.

Each threat out of the above-mentioned ones required the following:

- substantiating an algorithm that included actions and implementation mechanisms to be applied during multi-sectoral and multi-level interaction between Rospotrebnadzor's bodies and organizations and other executive authorities that took part in organizing a global mass event;

- implementing a set of risk-oriented control and surveillance activities concerning economic entities that belonged to 1-4 hazard categories as per potential health risks; results of this implementation were to be applied to divide a territory on which an event was organized into specific zones;

- creating a list of priority health risk factors that were subject to obligatory dynamic and (or) operative laboratory control at all stages during a global mass event;

- optimizing points and programs of social-hygienic monitoring taking into account number of people who participated in an event and ran a risk of exposure to chemical factors;

- indicating threats and quantitatively assessing current and predicted risks for sanitary-epidemiologic welfare at all stages during preparation and organization of an event as well as event itself; 
- providing information support and functioning of a multi-level system for information exchange.

All the above-mentioned tasks were successfully completed when local control and surveillance activities were performed during global mass events that were organized and held in the RF. It is confirmed by sanitary-epidemiologic welfare at such events being highly estimated by experts worldwide.

But still there were some difficulties, mostly concerning laboratory support for hygienic safety provision due to absence of unified approaches to solving issues related to screening laboratory research and tests [8].

Global mass events have a peculiarity, that is, they happen during a rather short period of time and from a hygienic point of view it means that guests and participants of such events are under short-term exposure to environmental factors. And as crowds of people gather in a very limited space, it imposes greater obligations to provide hygienic safety on an area where such an event takes place.

Insufficient laboratory control over chemical factors can cause threats to health of people who visit an event or participate in it; probability of such threats should be determined depending on a scale or geopolitical significant of a global mass event.

Clause 32 of the Federal Law issued on March 30, 1999 No. 52-FZ obliges an economic entity to perform industrial control, including laboratory research and tests, in order to make its activities safe and (or) harmless for people and the environment ${ }^{4}$.

Experts performed retrospective analysis of issues concerning laboratory support for hygienic safety provision that occurred during global mass events held in Russia. The analysis revealed a variety of factors exerting negative influence on quality and good timing of laboratory control, lowering its efficiency, and increasing expenses required to conduct it.

Problems exerting negative influence on laboratory support provided for global mass events were ranked and it enabled determining the most significant ones; thus, a leading factor was insufficient information-analytical support and a poorly structured information system that made it difficult to exchange information between different subjects in the process.

It is becoming even more a pressing issue to develop a basic concept of information-analytical support for laboratory control as terroristic threats that can possibly involve chemicals are growing and there can be newly created substances used in them that have not been stated openly and therefore can hardly be identified in environmental objects.

Laboratory control over chemical factors performed during preparation and organization of global mass events that had been already held revealed a low share of samples with adverse chemicals in concentrations higher than MPC. This can either be due to organizers and constructors having adhered to all the technological standards during preparation to and an event itself or due to insufficient laboratory control. Sometimes it is actually impossible to perform laboratory control during critical periods of preparation or an event itself and it is a grave issue that needs to be resolved.

Personnel employed at construction sites or dealing with repairing or preparing objects

\footnotetext{
${ }^{4}$ On sanitary-epidemiologic welfare of the population: The Federal Law No. 52-FZ issued on March 30, 1999 [Websource] // KonsultantPlus. -URL: http:www.consultant.ru/cons_doc (date of visit May 14, 2019).
} 
for a global mass event are exposed to all occurring chemical factors and exposure period for them is longer than a period of time during which an actual event takes place.

In this respect it seems advisable to implement a system for biological control over markers of impacts exerted by various chemicals on personnel involved into preparations to global mass events.

Results of the said biological monitoring will substantially increase authenticity of assessed health risks for guests and participants of a global mass event. Health risk assessment methodology that is officially recommended by global scientific society and officially applied in the RF suggests assessing a multi-factor risk as a sum of one-factor risks [7]. A suggested procedure for biological control provides a comprehensive solution to all the set tasks.
If this system is implemented, it will also allow making objects safer as regards possible terroristic threats involving chemicals; should any biological markers of effects produced by potentially hazardous chemicals be revealed among personnel involved in preparation and organization of an event, relevant authorities will have additional opportunities to perform prevention activities.

This model for laboratory control can be tested in 2020 when several global mass events are to take place in Russia such as UEFA Euro 2020 events in Saint Petersburg, AIBA World Boxing Championship in Yekaterinburg and Ufa in 2019, etc.

Funding. The research was not granted any sponsor support.

Conflict of interests. The authors state there is no any conflict of interests.

\section{References}

1. Popova A.Yu., Zaitseva N.V. Nauchno-metodicheskie aspekty otsenki riska zdorov'yu pri realizatsii funktsii i polnomochii Federal'noi sluzhby po nadzoru v sfere zashchity prav potrebitelei i blagopoluchiya cheloveka [Scientific and methodical aspects of health risk analysis when the Federal Service for Surveillance over Consumer Rights Protection and Human Well-being performs its functions and authorities]. Aktual'nye voprosy analiza riska pri obespechenii sanitarno-epidemiologicheskogo blagopoluchiya naseleniya i zashchity prav potrebitelei: materialy VIII Vserossiiskoi nauchno-prakticheskoi konferentsii s mezhdunarodnym uchastiem, Perm, 2018, pp. 9-14 (in Russian).

2. Popova A.Yu., Zaitseva N.V., May I.V. Opyt metodicheskoi podderzhki i prakticheskoi realizatsii risk-orientirovannoi modeli sanitarno-epidemiologicheskogo nadzora 2014-2017 gg [Experience in providing methodical support and implementation of a risk-oriented model for sanitaryepidemiologic surveillance (2014-2017)]. Aktualnye voprosy obespecheniia sanitarno-epidemiologicheskogo blagopoluchiia naseleniia na urovne subieekta Federatsii: materialy nauchno-prakticheskoi internet-konferentsii, Perm, 2017, pp. 7- 15 (in Russian).

3. Popova A.Yu., Rakitskii V.N. Gigiena: istoriya i sovremennost' [Hygiene: history and current situation]. Rossiiskaya gigiena - razvivaya traditsii, ustremlyaemsya v budushchee: materialy XII Vserossiiskogo sieezda gigienistov i sanitarnykh vrachei, Moscow, 2017, vol. 1, pp. 6-13 (in Russian).

4. XXVII Vsemirnaya letnyaya universiada 2013 goda v Kazani. Obespechenie sanitarnoepidemiologicheskogo blagopoluchiya [XXVII 2013 Summer Universiade in Kazan. Sanitaryepidemiologic welfare provision]. In: G.G. Onishchenko, V.V. Kutyrev eds. Tver', Triada Publ., 2013, 528 p. (in Russian).

5. XXII Olimpiiskie zimnie igry i XI Paralimpiiskie zimnie igry 2014 goda v g. Sochi. Obespechenie sanitarno-epidemiologicheskogo blagopoluchiya [XXII 2014 Winter Olympics and Paralympics in Sochi. Sanitary-epidemiologic welfare provision]. In: G.G. Onishchenko, A.N. Kulichenko eds. Tver', Triada Publ, 2015, 576 p. (in Russian). 
6. Udovichenko S.K., Toporkov A.V., Karnaukhov I.G., Safronov V.A., Kedrova O.V., Toporkov V.P., Kutyrev V.V. Evaluation of External and Internal Threats to Sanitary-Epidemiological Welfare of the Population in the Context of Mass Sporting Events. Problemy osobo opasnykh infektsii, 2013, no. 2, pp. 26-32 (in Russian).

7. Romanovich I.K., Barkovskii A.N., Titov N.V., Shevchenko G.T. Obespechenie radiatsionnoi bezopasnosti i protivodeistvie radiatsionnomu terrorizmu pri provedenii massovykh sportivnykh meropriiatii [Radiation safety provision and control of radiation terrorism during mass sport events]. In: G.G. Onishchenko, A.Yu. Popova eds. St. Petersburg, Federalnaia sluzhba po nadzoru $\mathrm{V}$ sfere zashchity prav potrebitelei i blagopoluchiia cheloveka Sankt-Peterburgskii nauchno-issledovatelskii institut radiatsionnoi gigieny im prof. P. V. Ramzaeva Publ., 2016, 364 p. (in Russian).

8. Imamov A.A., Balabanova L.A., Zamalieva M.A., Radchenko O.R. On planning of laboratory researches for ensuring sanitary and epidemiologic wellbeing during carrying out mass actions. Vestnik Rossiiskoi voenno-meditsinskoi akademii, 2015, vol. 49, no. 1, pp. 185-188 (in Russian).

9. Patyashina M.A., Balabanova L.A. Current problems of surveying sanitary and epidemiological well-being at public events with international participation. Kazanskii meditsinskii zhurnal, 2015, vol. 96, no. 1, pp. 90-95 (in Russian).

10. Enock K. E., Jacobs J. The Olympic and Paralympics Games 2012: literature review of the logistical planning Operational challenges for public health. Public Health, 2008, vol. 122, no. 11, pp. 1229-1238. DOI: 10.1016/j.puhe.2008.04.016.

11. Globalnye massovye meropriiatiia ikh znachenie i vozmozhnosti dlia obespecheniia bezopasnosti zdorovia v mire doklad sekretariata [Global mass events: their significance and opportunities to provide health safety worldwide: The WHO Secretariat Report]. World Health Organization, 2011, 8 p. Available at: http://apps.who.int/iris/bitstream/10665/25910/1/B130_17-ru.pdf (23.03.2019) (in Russian).

12. Popova A.Yu., Balakhonov S.V., Goriaev D.V., Dmitrieva G.M., Filatova S.A., Sharakshanov M.B., Vishniakov V.A., Mironova L.V., Zh.Yu. KHunkheeva, Sidorova E.A. [et al]. Estimation of risks of importations and distribution of dangerous infectious diseases during the xxix winter Universiade 2019 in Krasnoyarsk. Zdorov'e naseleniya i sreda obitaniya, 2018, no. 6, pp. 4-11 (in Russian).

13. Health advice for travellers to the 2018 FIFA World Cup in the Russian Federation. World Health Organization. Available at: http://www.who.int/foodsafety/publications/consumer/ en/travellers_en.pdf?ua=1 (01.02.2019).

14. Zaitseva N.V., May I.V., Kleyn S.V., Vekovshinina S.A., Balashov S.Yu. Practical experience in the assessment and management of non-infectious health risks during the preparation of the mass sports events (using the example of the 2013 Summer Universiade in Kazan and the 2014 Winter Olympics in Sochi). Zdorov'e naseleniya i sreda obitaniya, 2015, vol. 273, no. 12, pp. 4-7 (in Russian).

15. Kleyn S.V., Balashov S.Yu., Stepanov E.G., Davletnurov N.Kh. Trial hygienic assessment and minimizing environmental health risks during leaders council meeting of shanghai cooperation organization countries and meeting of leaders and government heads of BRICS countries held in Ufa. Health Risk Analysis, 2017, no. 2, pp. 73-87. DOI: 10.21668/health.risk/ 2017.2.08.eng

16. Rossiya $\mathrm{v}$ formirovanii mezhdunarodnoi sistemy profilaktiki rasprostraneniya oruzhiya massovogo porazheniya [Russia in creating an international system aimed at preventing spread of weapons of mass destruction]. In: A.D. Bogaturov ed. Moscow, KomKniga Moskva Publ., 2008, 208 p. (in Russian).

17. Vorob'ev Yu.L. Natsional'naya bezopasnost' i upravlenie strategicheskimi riskami v Rossii [National security and strategic risks management in Russia]. Strategiya grazhdanskoi zashchity: problemy i issledovaniya, 2013, vol. 3, no. 2, pp. 95-104 (in Russian). 
18. Vekovshinina S.A., Kleyn S.V., Balashov S.Yu., Nikiforova N.V., Ukhabov V.M. Olympic games 2014 in Sochi: selection of priority indicators and measures of management of health risk caused by chemicals. Zdorov'e sem'i - 21 vek, 2015, no. 3, pp. 9-25 (in Russian).

19. Enderlein U., Regmi J. Strengthening public health: making the case for mass gatherings. Public Health Panorama, 2018, vol. 4, no. 1, pp. 72-77.

20. Karpushchenko G.V. Methodology of laboratory control on different stages of mass events. Zdorov'e naseleniya i sreda obitaniya, 2018, vol. 303, no. 6, pp. 15-17(in Russian).

Popova A.Yu., Zaitseva N.V., Karpushchenko G.V. Scientific and methodological aspects of labpratory support aimed at providing chemical safety during internaitonal mass events. Health Risk Analysis, 2019, no. 2, pp. 14-20. DOI: 10.21668/health.risk/2019.2.02.eng

Received: 23.05.2019

Accepted: 19.06.2019

Published: 30.06.2019 